\title{
MENUJU SISTEM PENGENDALIAN MANAJEMEN BERTANGGUNG JAWAB SOSIAL STUDI PADA PT. PELINDO MARINE SERVICE SURABAYA
}

\author{
Nurul Kompyurini ${ }^{1}$
}

\author{
Program Studi Akuntansi \\ Fakultas Ekonomi dan Bisnis Universitas Trunojoyo Madura
}

\begin{abstract}
Article history:
Received 12 April 2019

Revised 14 Juni 2019

Accepted 17 Juni 2019
\end{abstract}

A R T I C L E I N F O

Key words:

corporate social responsibility, management control system

\begin{abstract}
A B S T R A C T
This study has two objectives. First, to find out how corporate social responsibility (CSR) is defined, and second, to find out whether CSR has been integrated in the management control system (MCS). The theoretical foundation is built from various research articles and literature on corporate social responsibility and management control systems. The object of this research was PT. Pelindo Marine Service Surabaya (PT. PMS). The data in this study comes from interviews with company management. The findings in this study are that the company cannot determine the objectives of social responsibility related to its stakeholders. This contributes to the absence of integration of social responsibility into the MCS. The lack of social responsibility goals related to stakeholder groups has caused the integration of these aspects into MCS to be hampered, and this has the potential to reflect the organization's seriousness in following its stakeholder approach.
\end{abstract}

\begin{abstract}
A B S T R A K
Studi ini memiliki dua tujuan. Pertama, adalah untuk mengetahui bagaimana tanggung jawab sosial perusahaan (corporate social responsibility/CSR) didefinisikan, dan kedua, untuk mengetahui apakah CSR telah terintegrasi di dalam sistem pengendalian manajemen (management control system/MCS). Landasan teoritis dibangun dari berbagai artikel penelitian dan literatur tentang tanggung jawab sosial perusahaan dan sistem pengendalian manajemen. Penelitian dilakukan di PT. Pelindo Marine Service Surabaya (PT. PMS). Data dalam penelitian ini bersumber dari wawancara yang dilakukan dengan manajemen perusahaan.

Temuan dalam penelitian ini adalah bahwa perusahaan masih belum dapat menetapkan tujuan tanggung jawab sosial yang terkait dengan pemangku kepentingannya. Hal ini berkontribusi pada tidak adanya integrasi tanggung jawab sosial ke MCS. Kurangnya tujuan tanggung jawab sosial yang terkait dengan kelompok pemangku kepentingan menyebabkan integrasi aspek-aspek ini ke dalam MCS menjadi terhambat, dan hal ini berpotensi dalam mencerminkan kekurangseriusan organisasi dalam mengikuti pendekatan pemangku kepentingannya.
\end{abstract}

\section{PENDAHULUAN}

Corporate Social Responsibility/tanggung jawab sosial perusahaan (CSR) menjadi unsur yang semakin penting dalam beberapa tahun terakhir, terutama bagi pemangku kepentingan. Perusahaan yang ingin berhasil, tidak hanya memperhitungkan kepentingan pemegang sahamnya saja, tetapi juga kelompok pemangku kepentingan lainnya, seperti pelanggan, karyawan, organisasi non-pemerintah, dan seluruh rantai nilai produk atau layanannya. Namun yang banyak terjadi, CSR tampaknya hanya berfungsi sebagai laporan rutin dan slogan iklan. Komitmen CSR ke depan untuk mencapai target kinerja secara eksplisit masih sangat jarang yang diterapkan oleh perusahaan (Porter dan Kramer, 2006, 81). CSR kini dapat menjadi sumber peluang, inovasi, dan keunggulan kompetitif bagi perusahaan. Perubahan dalam lingkungan operasi telah meningkatkan pentingnya aspek CSR. Misalnya, perubahan iklim adalah topik yang kini menjadi relevan dalam banyak diskusi. Perubahan iklim juga akan berdampak pada berbagai sektor di masa depan.

\footnotetext{
* Corresponding author, email address: ${ }^{1}$ nurulkompyurini2007@yahoo.co.id
} 
Tren ini menuju bisnis yang berkelanjutan di mana penciptaan nilai tidak hanya difokuskan pada istilah keuangan tetapi juga istilah ekologi dan sosial (Cramer, 2002).

Banyak perusahaan saat ini menerbitkan laporan tanggung jawab sosial perusahaan dan menyebutkan CSR menjadi strategis penting. Pelaporan tanggung jawab sosial perusahaan dan referensi untuk strategi menunjukkan bahwa masalah-masalah CSR juga dipertimbangkan secara internal dan bahwa CSR telah menjadi bagian dari sistem pengendalian manajemen. Namun untuk dapat mengelola CSR dengan sukses, dapat dilakukan dengan menerapkan strategi yang dipilih dan menindaklanjuti pemenuhan target melalui sistem pengendalian manajemen.

Penelitian tentang CSR telah banyak yang dipublikasikan, seperti misalnya penelitian tentang pelaporan CSR dan teori yang mendasarinya (Adams 2002, O`Dwyer, 2002, Adams and McNicholas, 2007). Namun topik tentang integrasi sistem pengendalian manajemen dan CSR masih belum banyak dilakukan, terutama dalam desain dan efeknya pada tingkat operasional. Morsing dan Oswald (2009) memberikan saran dalam studi kasus tentang manajemen berkelanjutan dan MCS, namun terdapat kekurangan utama dari kasus tersebut, yaitu bahwa dalam kasus tersebut hanya menggambarkan MCS dari pelopor CSR terkenal yang tidak menceritakan apa pun tentang realitas di sebagian besar perusahaan. Durden (2008) dalam penelitiannya juga mempertimbangkan MCS yang bertanggung jawab.

Pada saat ini kebanyakan penelitian menekankan aspek lingkungan secara umum, karena banyak terdapat fakta bahwa penelitian terutama difokuskan pada perusahaan industri dan manufaktur di mana perusahaan-perusahaan ini memiliki dampak lingkungan yang signifikan dan terkadang perusahaan juga melakukan penghematan biaya melalui pengelolaan lingkungan. Namun, CSR saat ini semakin menjadi tantangan bagi perusahaan jasa, dalam rangka untuk menanggapi permintaan dari para pemangku kepentingannya, baik internal maupun eksternal, yang menuntut pelaksanaan CSR yang lebih baik. Tujuan dari penelitian ini adalah untuk mengetahui bagaimana CSR didefinisikan dalam industri jasa kepelabuhanan, dan apakah CSR dibangun ke dalam sistem penendalian manajemen (MCS) dalam industri jasa kepelabuhanan, dan jika demikian bagaimana caranya.

\section{TELAAH LITERATUR}

\section{Tanggung Jawab Perusahaan}

\section{a. Mendefinisikan Tanggung Jawab Sosial Perusahaan}

Secara umum tanggung jawab sosial perusahaan merupakan peningkatan kualitas kehidupan, dimana manusia sebagai anggota masyarakat mampu menanggapi keadaan sosial yang ada, serta dapat menikmati, memanfaatkan dan memelihara lingkungan hidup, atau dapat dikatakan bahwa CSR adalah sebagai proses penting dalam pengaturan biaya yang dikeluarkan dan keuntungan kegiatan bisnis dari stakeholders baik secara internal (pekerja, shareholders dan penanam modal) maupun eksternal (kelembagaan, anggota-anggota masyarakat, kelompok masyarakat sipil, dan perusahaan lain). CSR merupakan komitmen usaha untuk bertindak secara etis, beroperasi secara legal, dan berkontribusi untuk peningkatan ekonomi bersamaan dengan peningkatan kualitas hidup dari karyawan dan keluarganya, komuniti lokal dan masyarakal secara lebih luas (Sankat, Clement K, 2002). Pengertian ini sama dengan apa yang dikemukakan oleh The World Business Council for Sustainable Development (WBCSD), yaitu CSR adalah komitmen bisnis untuk berkontribusi dalam pembangunan ekonomi berkelanjutan, bekerja dengan para karyawan perusahaan, keluarga karyawan tersebut, berikut komuniti-komuniti setempat (lokal) dan masyarakat secara keseluruhan, dalam rangka meningkatkan kualitas kehidupan.

Pembangunan berkelanjutan dan tanggung jawab sosial perusahaan telah terikat kuat dengan kehidupan bisnis selama beberapa dekade terakhir. Tanggung jawab sosial perusahaan mulai berkembang dari aspek lingkungan untuk mencakup keseluruhan triple bottom line. Banyak standar dan kebijakan telah mengarahkan kinerja lingkungan dan sosial organisasi mulai dari tahun 90 -an. Standar yang paling terkenal dan tersebar luas adalah sebagai berikut. The European Community's Eco-Management and Audit Scheme (EMAS) dan International Standard ISO-14001 adalah standar paling terkenal untuk pengelolaan lingkungan. ISO-14001 didirikan pada tahun 1996 dan menyediakan serangkaian standar proses. EMAS didirikan pada tahun 1993, dan direvisi pada tahun 2001, sebagai inisiatif sukarela untuk meningkatkan kinerja lingkungan. 


\section{b. Pelaporan Tanggung Jawab Sosial Perusahaan}

Pelaporan tanggung jawab sosial perusahaan dan kerangka pelaporannya yang paling dikenal adalah menggunakan Global Reporting Initiative (GRI). Dua teori pelaporan CSR yang paling banyak digunakan adalah teori legitimasi, yang membahas harapan secara umum, dan teori stakeholder yang berkonsentrasi pada kelompok tertentu dalam masyarakat yang dipilih oleh organisasi pelapor (Deegan dan Blomquist, 2006).

Adams (2002) menemukan bahwa motivasi utama dalam CSR dan pelaporan etis di perusahaan adalah untuk meningkatkan citra perusahaan dan kredibilitas para pemangku kepentingan. Namun, sebenarnya alasan utama untuk memulai pelaporan CSR adalah tekanan publik. O'Dwyer (2002) melakukan penelitian di Irlandia dengan informan adalah sebagian besar eksekutif senior, berpendapat bahwa motivasi utama untuk pelaporan CSR adalah untuk meningkatkan legitimasi perusahaan. Temuan ini mengimplikasikan bahwa pelaporan CSR dalam banyak kasus bukanlah pelaporan hasil yang berasal dari realisasi strategi CSR. Adams (2002) juga mengingatkan bahwa tidak hanya karakteristik perusahaan dan faktor kontekstual umum (seperti negara asal atau tekanan media) yang dapat mempengaruhi pelaporan CSR, tetapi juga faktor internal, termasuk didalamnya faktor proses dan sikap. Proses ini mencakup manajemen, struktur perusahaan dan tata kelola, perluasan dan sifat keterlibatan pemangku kepentingan, dan keterlibatan akuntan/pengontrol, sedangkan sikap mencakup sikap umum terhadap pelaporan CSR, budaya perusahaan, dan biaya yang dirasakan versus manfaat dari pelaporan. (Adams, 2002)

\section{c. Global Reporting Initiative}

Global Reporting Initiative (GRI) adalah inisiatif internasional untuk menciptakan kerangka pelaporan CSR secara umum (Niskala et al. 2009). GRI didirikan pada tahun 1997 dan sejak itu kerangka pelaporan GRI terus dikembangkan bersama dengan berbagai konsultasi pemangku kepentingan. Misi GRI adalah untuk memenuhi kebutuhan kerangka kerja konsep yang dibagikan secara global, bahasa yang konsisten, dan metrik untuk pelaporan CSR. GRI bertujuan untuk memungkinkan perbandingan kinerja keberlanjutan antara organisasi yang berbeda dan dari waktu ke waktu. Namun, variasi dalam periode pelaporan, batasan, ruang lingkup, dan panjang laporan adalah sangat besar. Perbandingan tersebut digunakan untuk membantu organisasi pelapor dalam menjelaskan batas pengaturan dan perubahannya seiring waktu (GRI RG, 2006).

Menurut GRI, laporan CSR harus memberikan gambaran yang seimbang tentang kinerja keberlanjutan dari organisasi pelapor termasuk kontribusi positif dan negatif. GRI menyatakan bahwa laporan CSR harus mengungkapkan keberlanjutan dalam konteks komitmen organisasi, strategi, dan pendekatan manajemen (GRI RG, 2006). GRI telah dikritik atas upayanya untuk membangun kerangka yang sesuai dengan organisasi dari berbagai ukuran, konstituensi, dan lokasi karena bidang dampak sosial dan lingkungan adalah sangat luas dan sangat bervariasi dari industri ke industri (Guthrie et al. 2008).

GRI menekankan bahwa organisasi pelapor dapat menentukan isi laporan - seluruh kerangka kerja tidak harus sepenuhnya tertutup untuk pelaporan pertama kalinya. Namun, ruang lingkup harus dijelaskan dan GRI mendorong pengungkapan rencana untuk memperluas pelaporan di masa depan. Pelaporan CSR adalah proses yang hidup dan pelaporan harus sesuai dengan gambaran tentang pengaturan strategi organisasi, penerapan rencana aksi, dan menilai hasilnya. Faktor eksternal dan internal harus dipertimbangkan, terlebih ketika memutuskan faktor mana yang harus diungkapkan. Faktor internal termasuk nilai-nilai utama organisasi, kebijakan, strategi, sistem manajemen operasional, sasaran dan target, minat pemangku kepentingan, risiko, faktor-faktor penting untuk keberhasilan organisasi, dan kompetensi inti organisasi. Pemangku kepentingan harus diidentifikasikan dan diungkapkan bagaimana organisasi menanggapi ekspektasi dan minat mereka.

Pedoman keberlanjutan GRI terdiri dari indikator kualitatif dan kuantitatif. Indikator inti sama untuk semua industri dan mereka harus dilaporkan kecuali dianggap tidak material untuk organisasi. Pendekatan manajemen harus disediakan untuk setiap kategori pelaporan dalam menetapkan konteks untuk informasi kinerja. Selain itu, tujuan organisasi untuk setiap kategori indikator juga harus dilaporkan. Gray (2006) melihat bahwa pendekatan tiga bagian yang sama untuk akuntabilitas, seperti kerangka GRI, di mana laporan tahunan akan terdiri dari tiga bagian yang sama, yaitu yang berkaitan dengan kegiatan ekonomi, sosial, dan lingkungan dari organisasi. Versi terbaru adalah Standar GRI yang diluncurkan pada awal 2017 lalu oleh Global Reporting Initiative (GRI) untuk menggantikan versi sebelumnya yaitu "Panduan G4". 


\section{d. Manfaat Bisnis dari CSR}

Pelaporan CSR dari perspektif perusahaan dapat memberikan manfaat untuk meminimalkan risiko, mengurangi kritik, kemungkinan untuk mempengaruhi atau menunda legislasi, menarik dan mempertahankan orang yang paling berbakat, menciptakan sistem internal dan control yang mengarah ke pengambilan keputusan yang lebih baik dan penghematan biaya, serta dapat mengomunikasikan nilai dan target (Adams 2002). Meskipun Adams menyebutkan manfaat dari pelaporan CSR, namun manfaat sebenarnya adalah berasal dari tindakan CSR yang dilakukan, bukan hanya sekedar dari pelaporannya saja. Pelaporan tanpa tindakan CSR yang sebenarnya akan sangat berisiko dan secara etis adalah salah. Gray (2006) menyatakan bahwa perilaku yang bertanggung jawab dan pelaporan CSR adalah indikasi dari organisasi yang dikelola dengan lebih baik dan bahwa manajemen memberi sinyal bahwa risiko yang terkait dengan masalah sosial dan lingkungan dikelola dengan benar.

Weber (2008) juga mengemukakan tentang manfaat bisnis yang berasal dari kegiatan CSR, yaitu adanya efek positif pada citra perusahaan, reputasi, motivasi karyawan, retensi dan rekrutmen, penghematan biaya, peningkatan pendapatan dari penjualan dan pangsa pasar yang lebih tinggi, serta CSR terkait dengan pengurangan atau manajemen risiko. Penghematan biaya cenderung menjadi cara termudah untuk memulai kegiatan CSR. Penghematan biaya dapat timbul dari substitusi material, konsumsi energi yang lebih rendah, pengurangan penyimpanan bahan dan biaya penanganan atau pengurangan pembuangan limbah (Epstein dan Roy, 2001).

\section{e. CSR Sebagai Bagian Dari Strategi}

Van den Brink dan van der Woerd (2004) mengatakan bahwa ketika mencoba mengatasi berbagai tantangan CSR, organisasi dapat mengembangkan strategi bisnis baru yang mencerminkan berbagai konteks dan situasi bisnis yang berbeda. Strategi yang berbeda dengan lingkungan operasi yang berbeda dapat meningkatkan CSR yang memang berbeda di antara berbagai organisasi. Tidak ada bisnis yang dapat menyelesaikan masalah sosial yang timbul atau menanggung biaya untuk melakukannya. Setiap perusahaan harus memilih isu-isu yang bersinggungan dengan bisnis dan menyajikan peluang untuk menciptakan nilai bersama, sehingga dapat menciptakan keunggulan kompetitif bagi perusahaan, serta disarankan juga bahwa perusahaan harus memprioritaskan masalah sosial. (Porter dan Kramer, 2006).

Porter dan Kramer (2006) menyarankan bahwa perusahaan harus memprioritaskan masalah sosial. Mereka menemukannya sebagai cara beralih dari CSR responsif ke CSR strategis, dengan langkahlangkah pertama, menentukan masalah sosial umum (CSR Responsif), yaitu masalah sosial yang tidak terpengaruh secara signifikan oleh operasi perusahaan atau secara material memengaruhi daya saing jangka panjangnya. Kedua, menentukan rantai nilai atas dampak sosial. Langkah ini adalah sebagai pendekatan daftar periksa untuk CSR di mana set standar risiko sosial dan lingkungan digunakan. GRI yang digunakan sebagai dasar untuk pelaporan Tanggung Jawab Sosial Perusahaan di banyak perusahaan, merupakan salah satu daftar periksa ini. Porter dan Kramer (2006) mengingatkan bahwa daftar ini (seperti GRI) merupakan titik awal yang sangat baik untuk implementasi CSR, tetapi perusahaan harus mengadopsi proses internal yang lebih proaktif dan disesuaikan agar benar-benar bertanggung jawab secara sosial. Dan ketiga, menentukan dimensi sosial dari konteks persaingan (CSR Strategis). Masalah sosial di lingkungan eksternal yang secara signifikan memengaruhi adalah pendorong utama daya saing perusahaan di lokasi tempat ia beroperasi.

Untuk dapat melakukan pergeseran, perusahaan harus membuat agenda sosial perusahaan, untuk mencapai manfaat sosial dan ekonomi secara bersamaan (Porter dan Kramer, 2006). Agenda sosial tentu saja akan didorong oleh misi, visi, dan nilai perusahaan. Agenda sosial yang terbentuk akan berbeda tergantung pada industri perusahaan dan area operasi. Perusahaan yang sama mungkin perlu menentukan peringkat masalah sosialnya secara berbeda jika beroperasi di banyak industri dan/atau di banyak lokasi yang memiliki karakteristik berbeda. Tujuan dari CSR yang benar-benar strategis adalah bahwa CSR sulit dibedakan dari bisnis sehari-hari. Sebelum strategi CSR dapat berhasil diimplementasikan pada kondisi tertentu, harus dipenuhi bahwa CSR harus menjadi bagian integral dari strategi perusahaan, kepemimpinan harus berkomitmen pada CSR dan membangun kapasitas organisasi tambahan, strategi CSR harus didukung dengan kontrol manajemen, pengukuran kinerja, dan sistem penghargaan, Strategi CSR harus didukung oleh misi, budaya, orang, terdapat integrasi CSR ke dalam semua keputusan strategis dan operasional, serta mengelola kinerja CSR yang tidak hanya sebagai penghindaran risiko tetapi juga sebagai peluang untuk inovasi dan keunggulan kompetitif (Epstein, 2008). 
Dari uraian tersebut di atas, dapat disimpulkan bahwa CSR adalah bidang yang cukup kompleks. Dengan demikian, sangat penting bagi setiap organisasi untuk mendefinisikan tentang CSR. Manfaat bisnis dan pelaporan atas pelaksanaan CSR telah banyak diungkap oleh berbagai penelitian di banyak industri. Kerangka kerja GRI memberikan panduan untuk proses pelaporan dan juga memfasilitasi perbandingannya. Jika menempatkan CSR sebagai bagian dari strategi dan bertindak sesuai dengan strategi tersebut, maka perusahaan/organisasi dituntut untuk mengatasi banyak tantangan, salah satunya yaitu perlunya memasukkan CSR ke dalam sistem kontrol manajemen perusahaan, dimana hal inilah yang menjadi topik dalam penelitian ini.

\section{Sistem Pengendalian Manajemen}

a. Mendefinisikan Sistem Pengendalian Manajemen

Seperti halnya CSR, sistem pengendalian manajemen (Management Control System/MCS) tidak memiliki definisi secara universal. Para peneliti telah menciptakan definisi mereka sendiri dan membentuk definisi yang sudah digunakan. Anthony (1965) mendefinisikan pengendalian manajemen pada tahun 60-an sebagai proses dimana para manajer memastikan bahwa sumber daya diperoleh dan digunakan secara efektif dan efisien dalam pencapaian tujuan organisasi.

Malmi dan Brown (2008) mendefinisikan sistem pengendalian manajemen sebagai sistem, aturan, praktik, nilai-nilai dan kegiatan manajemen lainnya yang diberlakukan untuk mengarahkan perilaku karyawan. Lebih lanjut, sistem pengendalian manajemen juga harus menjadi sistem yang lengkap, bukan hanya aturan sederhana, serta pentingnya memonitor pelaksanaannya.

Norris and O'Dwyer (2004) mengatakan bahwa sistem pengendalian manajemen terdiri dari tiga komponen, yaitu (1) menetapkan dan mengkomunikasikan tujuan, (2) memantau kinerja melalui pengukuran, dan (3) memotivasi karyawan untuk mencapai tujuan. Anthony dan Govindarajan (2004) mendefinisikan sistem pengendalian manajemen didasarkan pada unsur-unsur berikut: perencanaan strategis, penganggaran, alokasi sumber daya, pengukuran kinerja, evaluasi dan penghargaan, alokasi pusat tanggung jawab, dan penentuan harga transfer.

Komponen penting dalam sistem pengendalian manajemen adalah sistem insentif, yang mendorong manajer dan karyawan organisasi untuk mencapai target yang ditetapkan. Insentif adalah katalis untuk mendorong perilaku yang diinginkan untuk melaksanakan strategi. Bagian penting dari penerapan sistem insentif apa pun adalah memilih ukuran yang tepat untuk mengevaluasi karyawan. Metrik nonfinansial sering digunakan untuk mengukur keberhasilan dalam pengelolaan aset tidak berwujud (Cravens dan Oliver, 2006) CSR merupakan aset tidak berwujud.

Sejauh ini, pengukuran keuangan berbasis akuntansi telah dominan karena mereka relatif obyektif, dapat diandalkan dan dapat diverifikasi (Tuomela, 2005). Ada tiga fitur utama dari sistem pengendalian manajemen, yaitu (1) Pengendalian manajemen adalah aktivitas memberi dan menerima di mana satu kelompok orang (manajemen) mencoba memaksakan kontrol pada sub kelompok yang mengendalikan diri sendiri yang mengarah pada reaksi disfungsional dan hasil dari kontrol dapat benar-benar berbeda dari yang diperkirakan, (2) sistem pengendalian manajemen adalah struktur yang dibangun secara sosial, dan (3) banyak faktor kontekstual mempengaruhi konsekuensi dari aktivitas pengendalian. (Berry et al. 2009) Fitur-fitur ini perlu diingat ketika mempelajari, menafsirkan dan menganalisis sistem pengendalian manajemen. Yang perlu mendapat perhatian adalah bahwa penerapan sistem pengukuran itu mahal (Tuomela, 2005) dan membutuhkan banyak sumber daya.

Dalam penelitian ini, pengendalian strategis dan pengendalian manajemen tidak dipisahkan ketika berbicara tentang MCS karena kedua hal ini terlihat saling berhubungan terutama ketika berbicara tentang CSR di MCS. Sejak adaptasi CSR ke dalam MCS dan membangun sistem pengendalian yang bertanggung jawab adalah bidang penelitian yang relatif baru, definisi yang diambil dalam sistem pengendalian manajemen adalah cukup luas. Dalam penelitian ini sistem pengendalian manajemen didefinisikan sebagai proses, sistem, dan alat yang digunakan oleh manajemen untuk memandu perilaku organisasi dan karyawannya untuk memenuhi strategi dan target yang ditetapkan.

\section{b. Kerangka Sistem Pengendalian Manajemen}

Simons (1995) telah mengembangkan kerangka Levers Of Control, di mana sistem pengendalian manajemen dibagi menjadi empat kelompok. Empat kerangka kerja Levers Of Control digunakan dalam penelitian ini karena dirasakan bahwa hal tersebut dapat membantu untuk mengetahui peran CSR dan 
sistem pengendalian manajemen di perusahaan.

Empat Levers Of Control dapat dilihat dalam gambar 2. Pertama, sistem kepercayaan digunakan untuk menginspirasi dan mengarahkan pencarian peluang baru dalam organisasi. Sistem kepercayaan mendefinisikan tujuan dan arah organisasi melalui nilai-nilai organisasi. Sistem batas menetapkan batasan untuk pencarian peluang dengan menjelaskan domain kegiatan yang dapat diterima. Batasan didasarkan pada risiko bisnis yang ditentukan yang perlu dihindari. Sistem kontrol diagnostik dapat dilihat sebagai bagian sistem kontrol yang paling dikenal dan paling terlihat bagi peserta organisasi yang digunakan untuk memotivasi, memantau, dan menghargai pencapaian target spesifik yang ditetapkan untuk menerapkan strategi. Tindakan korektif dapat diambil berdasarkan hasil dari sistem kontrol diagnostik. Merancang sistem kontrol diagnostik memerlukan analisis dan pemahaman yang cermat terhadap variabel kinerja yang penting dari organisasi. Sistem kontrol interaktif untuk bagian mereka merangsang pembelajaran organisasi dan munculnya ide-ide dan strategi baru. Estimasi ulang terus-menerus terhadap keadaan masa depan dan pertimbangan tentang cara terbaik bereaksi terhadap masa depan dilakukan melalui sistem kontrol interaktif. (Simons 1995).

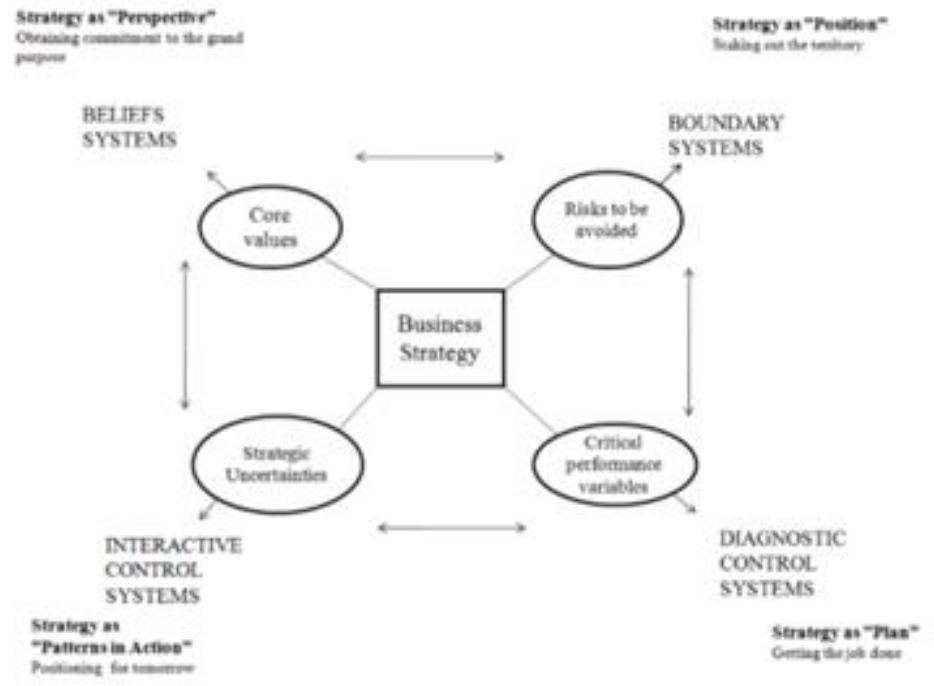

Gambar 1. Empat Levers Of Control

Sumber : Simons 1995

CSR dapat dibangun ke dalam empat bagian Levers Of Control. Dalam sistem kepercayaan, CSR dapat dimasukkan ke dalam proposisi nilai, misi, atau pernyataan nilai. Selain itu, dalam sistem boundary, CSR dapat menjadi bagian dari kode perilaku bisnis dan sistem perencanaan strategis. Sistem kontrol diagnostik memiliki peran penting untuk memastikan bahwa strategi sedang diikuti - CSR dapat tidak terlihat dalam pengaturan standar, mengukur output dan menghubungkan insentif untuk mencapai target. Sistem kontrol interaktif dapat berarti, misalnya, mengumpulkan data tentang perubahan dan tren masa depan dalam industri dan memperdebatkan masalah ini dan fitur-fiturnya yang memungkinkan menciptakan ketidakpastian strategis - CSR dapat menjadi salah satu ketidakpastian strategis melalui perubahan perilaku pesaing dan / atau persyaratan pelanggan.

\section{c. CSR Dalam Sistem Pengendalian Manajemen}

CSR diperlukan untuk dimasukkan ke dalam sistem pengendalian manajemen untuk dapat memantau apakah bisnis beroperasi sesuai dengan CSR yang sudah ditetapkan dalam organisasi dan sasaran pemangku kepentingan. Keberadaan CSR yang terfokus dalam sistem pengendalian manajemen akan memperkuat pandangan bahwa perusahaan sedang berusaha untuk beroperasi secara bertanggung jawab daripada hanya melakukan peningkatan citra. Norris dan O`Dwyer (2004) merumuskan bahwa agar terdapat respon sosial perusahaan, maka perlu didukung oleh sistem kontrol manajemen yang mempromosikan atau melembagakan pengambilan keputusan secara komprehensif. Durden (2008) menyatakan bahwa hal tersebut akan menjadi tidak konsisten dan bermasalah bagi perusahaan, namun di sisi lain hal ini dapat menghasilkan informasi CSR eksternal dan mengklaim operasi perusahaan dilakukan secara bertanggung jawab (Jung et al. 2001). Kurangnya definisi sistematis CSR dapat disebut sebagai 
hambatan utama untuk mengintegrasikan CSR ke dalam operasi organisasi. Identifikasi definisi umum sangat penting bagi perusahaan untuk mengelola CSR dalam perusahaan.

Penelitian ini memodifikasi kerangka kerja Durden. Fase pertama adalah menentukan definisi CSR sebagai titik awal untuk membangun CSR ke dalam sistem pengendalian manajemen. Pada tahap ketiga, sistem pengendalian manajemen dibentuk dan ini mewakili proses, sistem, dan alat yang digunakan oleh manajemen untuk memandu perilaku organisasi dan karyawannya untuk memenuhi strategi dan target yang ditetapkan. Untuk memfasilitasi tindakan manajemen, manajemen harus mendapatkan pelaporan yang tepat dari langkah ketiga. Setelah mencapai hasil CSR, hasil ini dapat dilaporkan kepada pemangku kepentingan melalui pelaporan CSR. Langkah-langkah ini akan digunakan untuk menganalisis hasil empiris dari penelitian. Tahap penyelarasan CSR ke dalam sistem pengendalian manajemen akan dianalisis sesuai dengan kerangka Durden.

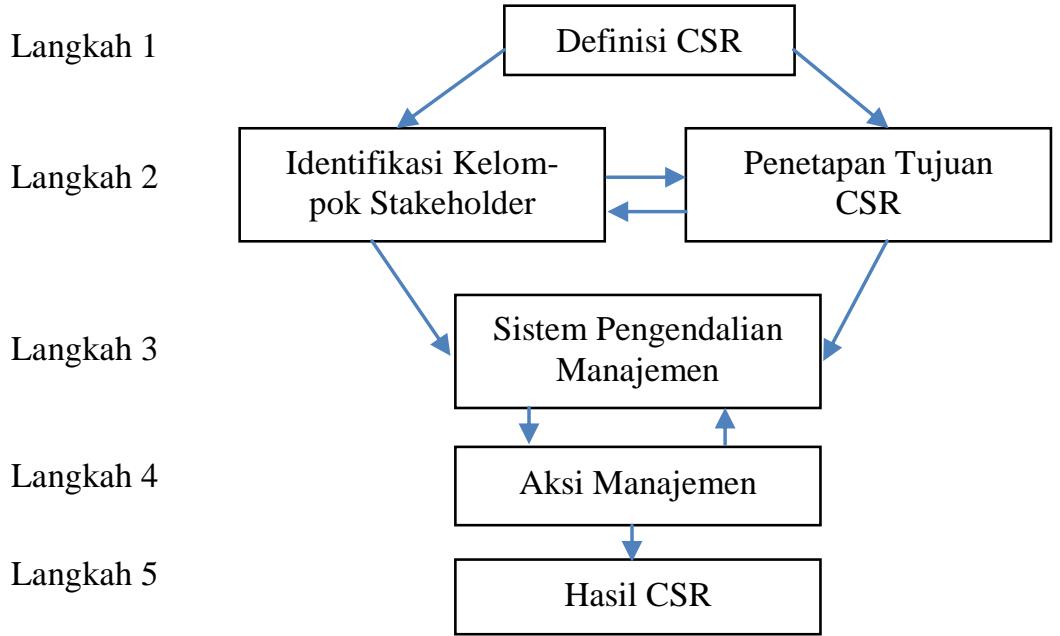

Gambar 2. Membangun CSR dalam MCS

Kerangka kerja tersebut di atas menunjukkan hubungan antara MCS dan tanggung jawab sosial, serta langkah-langkah yang diperlukan oleh pemangku kepentingan dan tujuan tanggung jawab sosial yang hendak diterapkan di dalam perusahaan. Dalam hal ini kerangka kerja dimulai dengan mengidentifikasi kelompok pemangku kepentingan yang relevan yang saling terkait dengan pengembangan tujuan tanggung jawab sosial. Proses ini adalah satu arah, dalam arti bahwa organisasi memandang tanggung jawab sosial adalah dari perspektifnya sendiri dan bukan dalam hubungannya dengan para pemangku kepentingan. Hubungan antara tanggung jawab social dan pemangku kepentingan adalah timbal balik, yang menunjukkan bahwa tujuan tanggung jawab sosial harus dikembangkan bersama dengan dan untuk mencerminkan kebutuhan para pemangku kepentingan. Tujuan tanggung jawab sosial harus relevan dengan kelompok pemangku kepentingannya, dan selanjutnya bagaimana mereka terhubung dengan kelompok-kelompok pemangku kepentingan tertentu kemudian dimasukkan ke dalam MCS. Langkah inilah yang merupakan titik keterkaitan yang utama antara teori pemangku kepentingan dan MCS.

\section{Mengukur CSR}

Perusahaan membutuhkan sistem yang tepat untuk mengendalikan perilaku dan pencapaian CSR mereka untuk dapat menilai apakah perusahaan menanggapi kekhawatiran pemangku kepentingan (Perrini dan Tencati, 2006) serta mencapai target dan sasaran CSR mereka sendiri. Pengukuran kemajuan CSR adalah salah satu elemen inti yang dapat digunakan untuk menjawab kebutuhan informasi bagi para pemangku kepentingan. Terdapat pandangan dari pemangku kepentingan bahwa kapasitas perusahaan untuk menghasilkan kekayaan dan nilai yang berkelanjutan dalam jangka panjang adalah ditentukan oleh adanya hubungan dengan para pemangku kepentingan (Post et al. 2002). Dengan demikian, perusahaan harus menganalisis kelompok pemangku kepentingan mana yang penting untuk kelangsungan hidupnya dalam jangka panjang dan hubungan mana yang menciptakan keunggulan kompetitif. Identifikasi dan pengukuran strategi CSR adalah sulit, karena CSR biasanya mewakili horizon waktu yang panjang, adanya tingkat ketidakpastian, dan dampak yang tinggi yang sulit diukur (Epstein dan Roy, 2001). 


\section{METODE PENELITIAN}

Penelitian ini adalah studi kasus deskriptif yang memberikan gambaran secara keseluruhan dari keadaan tanggung jawab sosial perusahaan dalam sistem pengendalian manajemen di PT. Pelindo Marine Service Surabaya. Metode studi kasus deskriptif dipilih untuk mendukung tujuan penelitian. Dalam penelitian akuntansi manajemen, studi kasus deskriptif menggambarkan sistem akuntansi, teknik dan prosedur yang saat ini digunakan dalam praktek.

Pada akhir bagian ini, perusahaan kasus disajikan dari sudut pandang CSR untuk memperkenalkan keadaan CSR di perusahaan yang diteliti. Berdasarkan tinjauan pustaka, basis wawancara semi-terstruktur akan disiapkan dan wawancara akan diambil untuk mempelajari tujuan penelitian di lapangan. Pengumpulan data dilakukan dengan wawancara tema semi-terstruktur. Wawancara dilakukan di perusahaan dan ditranskripsikan untuk tujuan analisis. Transkripsi diperiksa secara seksama dan koreksi dilakukan jika diperlukan.

Informan dalam penelitian ini adalah orang-orang yang memiliki pengetahuan terbaik tentang CSR di MCS, yaitu Direktur Sumber Daya Manusia dan Keuangan dan SVP (Senior Vice Prosident) SDM dan Keuangan. Wawancara dilakukan antara 5 - 16 Nopember 2018. Wawancara berlangsung sekitar 50 menit. Materi wawancara adalah aspek-aspek sebagai berikut:

a. Bagaimana perusahaan mendefinisikan CSR?

b. Stakeholders

c. Lingkup pelaporan CSR

d. Kehadiran triple bottom line

e. Apakah CSR disebut strategis dan penting? CSR dalam nilai-nilai?

f. Apakah proses internal, sistem pengendalian manajemen atau pengukuran yang disebutkan saat berbicara tentang CSR?

g. Komitmen manajemen

h. Kehadiran pengaturan tujuan CSR

\section{HASIL PENELITIAN DAN PEMBAHASAN}

PT. Pelindo Marine Service (PMS) merupakan anak perusahaan PT. Pelabuhan Indonesia (Pelindo) III (Persero) yang dirintis sejak tahun 2005. Sektor maritim merupakan salah satu prioritas dalam program kinerja pemerintahan Presiden Joko Widodo untuk mewujudkan Indonesia sebagai poros maritim dunia. Salah satu strategi pemerintah ialah dengan membangun infrastruktur seperti pelabuhan, tol laut dan sebagainya untuk meningkatkan efisiensi distribusi logistik di berbagai wilayah Indonesia.

PT. PMS sebagai perusahaan di bawah PT. Pelindo III membantu mewujudkan program kerja pemerintah melakukan strategi bisnis unit sebagai berikut:

a. Pada tahun 21 April 2014 telah berdiri PT. Alur Pelayaran Barat Surabaya (PT. APBS) yang bergerak di bidang konstruksi bangunan pelabuhan dan dermaga, pengerukan dan penyiapan lahan.

b. Pada akhir tahun 9 September 2014 telah berdiri PT. Pelindo Energi Logistik (PT. PEL) yang bergerak di bidang rantai pasok energi BBM dan gas alam cair/Liquefied Natural Gas (LNG).

c. Pada tahun 30 Agustus 2017 telah berdiri PT. Berkah Multi Cargo (PT. BMC) yang bergerak di bidang angkutan multimoda nasional dan internasional.

Ketiga bisnis unit tersebut masih baru berada di bawah PT. PMS Group dan memiliki bidang usaha yang berbeda-beda.

Ringkasan keadaan CSR dalam kasus perusahaan dapat dilihat dalam tabel di bawah ini.

Table 1.

Ringkasan Keadaan CSR di PT. PMS

\begin{tabular}{|l|l|}
\hline \multicolumn{1}{|c|}{ Keterangan } & \multicolumn{1}{|c|}{ PT PMS } \\
\hline Definisi CSR & Sebagai bagian integral dari bisnis \\
\hline Stakeholders & $\begin{array}{l}\text { Shareholders, konsumen (pengguna jasa), } \\
\text { investor, pemerintah, partner bisnis }\end{array}$ \\
\hline $\begin{array}{l}\text { Lingkup pelaporan } \\
\text { CSR }\end{array}$ & Tidak ada \\
\hline
\end{tabular}




\begin{tabular}{|l|l|}
\hline Triple bottom line & $\begin{array}{l}\text { Ya, menekankan secara kuat dalam tanggung } \\
\text { jawab secara ekonomi }\end{array}$ \\
\hline CSR goal setting & Target CSR hanya disebutkan secara umum \\
\hline Strategi CSR & Strategi CSR terpisah \\
\hline Nilai-nilai CSR & $\begin{array}{l}\text { Pelaksanaan CSR sangat ditentukan oleh } \\
\text { nilai-nilai }\end{array}$ \\
\hline CSR dalam MCS & Tidak disebutkan \\
\hline
\end{tabular}

CEO Perusahaan menyatakan bahwa perusahaan berusaha menjadikan CSR sebagai bagian integral dari bisnis. Perusahaan ingin menjadi anggota masyarakat yang bertanggung jawab dan memberikan layanan jasa kepelabuhanan kepada pelanggannya dengan persyaratan yang kompetitif. Perusahaan juga memperbarui strategi dan prioritas CSR dan meluncurkan beberapa inisiatif untuk pengembangan lebih lanjut. Dua hal yang menjadi fokus dari strategi CSR adalah (1) Kegiatan untuk meningkatkan kesadaran, penerimaan, dan perilaku kinerja yang ditingkatkan di antara karyawan dan (2) Kegiatan operasional dan kualifikasi yang membuat Perusahaan dapat memenuhi target dan komitmen CSRnya. Target yang lebih spesifik atau sistem pemantauan tidak disebutkan, serta tidak disebutkan apakah aspek CSR termasuk dalam strategi keseluruhan, seperti yang disampaikan oleh SVP (Senior Vice President) SDM dan Umum sebagai berikut :

“Jika ditanya apakah kami menganggap ini (CSR) menjadi strategi penting jawabannya adalah ya. Saya memiliki kesan kuat bahwa manajemen berkomitmen untuk masalah ini, dan saya rasa CSR mencakup secara luas di semua operasi perusahaan. Hanya saja, CSR di perusahaan kami adalah dalam bentuk Program Kemitraan dan Bina Lingkungan. Program ini meliputi dua kegiatan, yaitu kemitraan yang ditujukan bagi UKM dan bina lingkungan untuk pembangunan lingkungan, seperti misalnya membangun rumah ibadah, atau juga ikut berpartisipasi dalam menanggulangi bencana alam".

Perusahaan dalam konteks laporan CSR juga telah mengkomunikasikan dampaknya kepada para pemangku kepentingan. Para pemangku kepentingan eksternal yang paling penting adalah pemegang saham dan pelanggan, sedangkan pemangku kepentingan internal adalah personel. CSR perusahaan sangat ditentukan oleh nilai-nilai yang di dalamnya juga terdapat dua kelompok pemangku kepentingan yaitu pelanggan dan karyawan.

Triple bottom line hadir dalam laporan CSR perusahaan. Dalam laporan tersebut, banyak penekanan diberikan pada komitmen perusahaan, baik internal maupun eksternal. Hal ini sesuai dengan tujuan yang ingin dicapai oleh perusahaan, yaitu :

“Turut serta melaksanakan dan menunjang kebijaksanaan dan program pemerintah dibidang ekonomi dan pembangunan nasional. Hal tersebut dilakukan dengan usaha di bidang pelayanan jasa perkapalan terhadap para pengguna jasa kemaritiman baik nasional maupun internasional, dengan memberikan pelayanan prima yang mengedepankan prinsip-prinsip Good Corporate Governance dan menerapkan prinsip-prinsip perseroan terbatas".

Tujuan tersebut dapat dicapai melalui tindakan-tindakan sebagai berikut :

a. Menjalankan usaha berfokus pada pertumbuhan dan produktivitas perusahaan.

b. Meningkatkan kualitas human capital, information system capital, dan organization capital untuk keberhasilan perusahaan yang keberlanjutan

c. Menjalankan usaha secara sinergi untuk meningkatkan keunggulan kompetitif perusahaan

d. Meningkatkan company brand equity melalui excellence marine service dengan mengedepankan kepuasan pelanggan

Dari hasil wawancara yang dilakukan, mengungkapkan bahwa perusahaan memiliki beberapa referensi tanggung jawab sosial perusahaan dalam sistem pengendalian manajemen mereka. Namun demikian, sistem tersebut sejauh ini dikembangkan tanpa memikirkan untuk membangun CSR ke dalam sistem pen- 
gendalian manajemen dan keberadaan CSR di MCS lebih terlihat ketika berbicara tentang aspek finansial dan sosial. Jadi, secara umum, meskipun CSR telah dilakukan oleh perusahaan secara berkelanjutan, namun perusahaan belum membangun CSR ke dalam MCSnya, seperti yang dikemukakan oleh Direktur SDM dan Keuangan sebagai berikut :

“Ini (CSR) ada dalam nilai-nilai kami juga ... Tapi kami masih harus banyak melakukan pengembangan yang harus dilakukan ke depannya agar sistem yang ada di perusahaan kami menjadi lebih baik lagi, dengan menyeimbangkan baik faktor ekonomi maupun sosial. Pengaturan target, pemantauan, pengukuran dan pelaporannya nantinya akan bersifat terbuka".

Dari pernyataan tersebut, dapat ditarik suatu kesimpulan bahwa tanggung jawab sosial perusahaan adalah bidang yang relatif baru di perusahaan, dan mensinergikan CSR dalam sistem pengendalian manajemen juga merupakan subjek yang belum tersentuh di perusahaan. Perusahaan memang melihat kasus CSR dari segi bisnis, yaitu karyawan dan pelanggan yang lebih puas serta mengarah pada pengembalian yang lebih baik dan citra perusahaan yang lebih tinggi. Perusahaan yang lebih sukses pada akhirnya mengarah pada kesejahteraan yang lebih baik bagi seluruh masyarakat yang beroperasi di dalamnya. Jadi, perusahaan berusaha agar bisnis sehari-hari dijalankan dengan cara yang bertanggung jawab, sehingga pada akhirnya akan dapat memberikan manfaat bagi sekitarnya.

\section{SIMPULAN, KETERBATASAN DAN SARAN}

Terdapat banyak faktor yang mempengaruhi kegiatan CSR dan sistem pengendalian manajemen. Perusahaan saat ini melaksanakan kedua kegiatan ini, namun perusahaan menganggap bahwa CSR melekat pada operasional perusahaan. Hasil dari studi wawancara dalam penelitian ini masih belum mendalam dan dapat menciptakan landasan untuk melakukan penelitian lebih lanjut, dimana CSR harus dianggap sebagai unsur dalam pembentukan MCS. Tanggung jawab sosial perusahaan adalah topik yang semakin penting.

Temuan penting dalam penelitian ini adalah bahwa organisasi ini masih belum dapat menetapkan tujuan tanggung jawab sosial yang terkait dengan kelompok pemangku kepentingan tertentu. Hal ini berkontribusi pada tidak adanya integrasi tanggung jawab sosial ke MCS. Dalam rencana strategis yang ditetapkan menyoroti upaya merangkul praktik bisnis yang bertanggung jawab secara sosial, namun, rencana tersebut tidak merujuk pada bagaimana hal ini dapat dicapai atau menargetkan kelompok pemangku kepentingan tertentu. Laporan yang berkaitan dengan triple bootom line bagi perusahaan tampak sekedar kegiatan publisitas, serta informasi yang disajikan sebagian besar bersifat deskriptif dan kurang mencerminkan kerangka kerja pelaporan yang sistematis. Dengan demikian, kurangnya tujuan tanggung jawab sosial yang terkait dengan kelompok pemangku kepentingan menghambat integrasi aspek-aspek ini ke dalam MCS. Integrasi tanggung jawab sosial ke dalam MCS akan menjadi masalah apabila tidak ada kejelasan tujuan tanggung jawab sosial dan pengukuran operasionalnya, dan hal ini berpotensi dalam mencerminkan kekurangseriusan organisasi dalam mengikuti pendekatan pemangku kepentingannya.

Berdasarkan temuan dalam penelitian ini, telah diusulkan kerangka kerja konseptual normatif yang menyediakan integrasi tanggung jawab sosial ke dalam MCS. Penelitian di masa depan dapat dilakukan dengan melakukan penyelidikan terhadap penerapan kerangka yang diusulkan tersebut, terutama dalam hal desain MCS yang berkaitan dengan tanggung jawab sosial perusahaan.

\section{DAFTAR PUSTAKA}

Adams, C.A. 2002. Internal organizational factors influencing corporate social reporting and ethical reporting: Beyond current theorizing, Accounting, Auditing and Accountability Journal Vol. 15 No. 2: 223-250.

Adams, C.A., McNicholas P. 2007. Making a difference. Sustainability reporting, accountability and organizational change, Accounting, Auditing and Accountability Journal Vol. 20 No. 3: 382-402.

Anthony, R.N. 1965. Planning and Control Systems: A Framework for Analysis. Harvard Business School Press, Boston.

Anthony, R.N., Govindarajan V. 2004. Management Control Systems. Eleventh Edition, McGraw-Hill, New York.

Berry, A.J., Coad, A.F., Harris, E.P., Otley, D.T., Stringer, C. 2009. Emerging themes in management control: A review of recent literature, The British Accounting Review 41, 2-20. 
Cramer, J. 2002. From Financial to Sustainable profit, Corporate Social Responsibility and Environment Management, 9, 99-106.

Cravens, K.S., Oliver, E.G. 2006. Employees: The key link to corporate reputation management, Business Horizons 49, 293-302.

Deegan, C., Blomquist, C. 2006. Stakeholder influence on corporate reporting: An exploration on the interaction between WWF-Australia and the Australian minerals industry, Accounting, Organizations and Society, 31, 343-372.

Durden, C. 2008. Towards a socially responsible management control system, Accounting, Auditing and Accountability Journal Vol. 21 No. 5, 671-694

Epstein, M.J., Roy, M-J. 2001. Sustainability in Action: Identifying and Measuring the Key Performance Drivers, Long Range Planning 34, 585-604.

Gray, R. 2006. Social, environmental and sustainability reporting and organizational value creation? Whose value? Whose creation?, Accounting, Auditing and Accountability Journal, Vol. 19 No. 6, 793-819.

Guthrie, J., Cuganesan, S., Ward, L. 2008. Industry specific social and environmental reporting: The Australian Food and Beverage Industry, Accounting Forum 32, 1-15.

Jung, E.J., Kim, J.S., Rhee, S.K. 2001. The measurement of corporate environmental performance and its application to the analysis of efficiency in oil industry, Journal of cleaner production, 9, 551-563.

Malmi, T., Brown, D.A. 2008. Management control systems as a package - Opportunities, challenges and research directions, Management Accounting Research, 19, 287-300.

Morsing, M., Oswald, D. 2009. Sustainable leadership: management control systems and organizational culture in Novo Nordisk A/S, Corporate Governance, Vol. 9 No.1, 83-99.

Niskala, M., Pajunen, T., Tarna-Mani, K. 2009. Yhteiskuntavastuun raportointi, raportointi- ja laskentaperiaatteet, KTH-Media Oy, Keuruu.

Niskala, M., Pretes, M. 1995. Environmental reporting in Finland: A note on the use of annual reports, Accounting, Organizations and Society 20 (6):457-466.

Norris, G., O'Dwyer, B. 2004. Motivating socially responsive decision making: the operation of management controls in a socially responsive organization, The British Accounting Review, 36, 173-196.

O'Dwyer, B. 2002. Managerial perceptions of corporate social disclosure - An Irish Story, Accounting, Auditing and Accountability Journal, Vol. 15 No. 3, 406-436.

Perrini, F., Tencati, A. 2006. Sustainability and Stakeholder Management: The Need for New Corporate Performance Evaluation and Reporting Systems, Business Strategy and the Environment 15, 296-308.

Porter, M.E., Kramer, M.R. 2006. Strategy \& Society. The Link Between Competitive Advantage and Corporate Social Responsibility, Harvard Business Review, Vol. 84 Issue 12, 78-92.

Post, J.E., Preston, L.E., Sachs, S. 2002. Managing the Extended Enterprise: The New Stakeholder View. California Management Review 45(1), 6-28.

Simons, R. 1995. Levers of Control, Harvard Business School Press, Boston.

Tuomela, T-S. 2005. The interplay of different levers of control: A case study of introducing a new performance measurement systems, Management Accounting Research, 16, 293-320.

van den Brink, T. van der Woerd, F. 2004. Industry Specific Sustainability Benchmarks: An ECSF Pilot Bridging Corporate Social Sustainability with Social Responsible Investments, Journal of business Ethics, $55,187-203$.

Weber, M. 2008. The business case for corporate social responsibility: A company-level measurement approach for CSR, European Management Journal, 26, 247-261. 